\title{
Assessment of Spatio-Temporal Changes in Land Use Pattern in North- Eastern Karnataka Region
}

\author{
G. Anupama ${ }^{1}$, B. S. Reddy ${ }^{2 *}$, Suresh S. Patil ${ }^{3}$, G. M. Hiremath ${ }^{4}$ and V. B. Wali ${ }^{5}$ \\ ${ }^{1}$ Department of Agricultural Economics, UAS, Raichur, 584104, India \\ ${ }^{2}$ Agricultural Extension Education Centre, Bheemarayanagudi-585 287, India
}

*Corresponding author

\section{Ke ywords \\ Area sown, Growth rate, Forest, Land use pattern, Markov chain analysis \\ Article Info \\ Accepted: \\ 15 January 2020 \\ Available Online: \\ 10 February 2020}

\section{A B S T R A C T}

Land utilization pattern differs from one region to other. Land availability, type of land and soil type are the main determinants of crops to be grown. The dynamics of shift among different land-use classes has been studied in the North- Eastern Karnataka region. A significant decline has been observed in the total reported area, which necessitates a proper land-use survey through remote sensing. A declining trend has also been observed in the area under forests. The unfavourable increasing trends in the area put to non-agricultural uses and the growth rate in land put to non-agricultural uses was significantly increased. In contrary, area under permanent pastures and other grazing lands declined in the study districts. The positive growth in net area sown was noticed in Kalaburgi $(0.20 \%)$ and Koppal (0.56\%) districts while negative growth was observed in Ballari (-1.36\%), Bidar $(-0.70 \%)$ and Raichur $(-0.56 \%)$ districts. Markov chain analysis showed that the area under forest, other uncultivable land excluding fallow land and net sown area were stable during study period. However, net sown area and fallow land were more stable in 1995-96 to 2004-05 compared to 2005-06 to 2014-15.

\section{Introduction}

The land is a prime factor in the factors of production and is an inelastic and immobile nature. Demand for land is increasing continuously for different sectorial development such as food grain production, fruits and vegetable production, meat production, road corridor, infrastructure, real estate, etc. The supply of land cannot be influenced by those factors but the land conversion can be possible among different land use categories.

Agriculture is a land-based activity and as such land and water have been the basic elements of life-support system and an important resource for the economic life of a majority of people in the world. The way people handle and use land resource is decisive for their social and economic wellbeing as well as for the sustained quality of 
land resources. India, with only 2.3 per cent of world's total land area supports 18 per cent of human and 15 per cent of livestock population in the world. According to the National Remote Sensing Agency's (NRSA) report, there are 75.5 million hectares of wastelands in the country of which around 58 million hectares are treatable and can be brought into productive levels through appropriate measures. However, the per capita arable land in the country is only 0.15 ha, which is expected to come down to nearly 0.08 ha by 2025 (Ramesh and Chand, 2009).

It is a paradoxical situation that on the one hand more production is required from the scarce soil resources for meeting the demand of ever-expanding population, while on the other, cultivable areas are being shifted towards non-agricultural uses. Land-use is a highly dynamic process. It implies that policy discussions and development planning have to be based on a sound understanding of these dynamics. Therefore, it is imperative to make a comprehensive study of the pattern and magnitude of land-use shifts for sustainability and productivity of agriculture in an area.

Dynamics of land use is a complex phenomenon which is affected by several socio-economic, agro-climatic and ecological variables. Both climatic and institutional factors are crucial in determining land use pattern. The extent of land use is also influenced by technological changes over a period of time. The technological changes in agriculture ignited intensive cultivation resulting in conversion of marginal lands into productive agricultural lands through capital intensive cultivation.

Total geographical area was about 43, 53,507 hectares in North Eastern Karnataka (NEK) during 2014-15. Forest area accounted 5.50 per cent, barren and uncultivable land and land put to non-agricultural uses occupied
3.93 per cent and 6.00 per cent respectively. Permanent pastures, cultivable wastes and land under miscellaneous trees crops correspondingly covered 2.09 per cent, 1.57 per cent and 0.68 per cent. Current fallows and fallows other than current fallow accounted 11.13 per cent and 4.94 per cent respectively. Net sown area occupied 64.16 per cent of the total reported area (Anon, 2015).

\section{Materials and Methods}

The present study was based on both primary and secondary data. Secondary data obtained from Directorate of Economics and Statistics(DES),Bangalore to analyze the land use pattern in North Eastern Karnataka region which includes Ballari, Bidar, erstwhile Kalaburgi, Raichur and Koppal districts, using past 20 years data from 1995-96 to 2014-15. It has been divided into two periods viz., period-I (1995-96 to 2004-05) and period II (2005-06 to 2014-15) and overall period (1995-96 to 2014-15) to study the changes in the land use pattern in the study area.

\section{Estimation of growth rate}

Compound growth rates of various land use categories were worked out on the basis of log-linear regression equation in selected district of NEK region and NEK region as a whole. The linear, log-linear, exponential and power functions are some of the important functional forms employed to study the growth rates. Some of the important forms tried were the linear growth model $(\mathrm{Y}=\mathrm{a}+$ $b t)$, exponential function $\left(Y=a b^{t}\right)$ and quadratic function $\left(\mathrm{Y}=\mathrm{a}+\mathrm{bt}+\mathrm{ct}^{2}\right)$. However, it was found that the exponential form of the function $Y_{t}=a b^{t}$ is the better and most frequently used one. Hence, in the present study the growth in the area under different land use categories was estimated using the exponential growth function of the form: 
$Y_{t}=a b^{t} U_{t}$

Where,

$\mathrm{Y}_{\mathrm{t}}=$ Land use categories in year' $\mathrm{t}^{\prime}$

$\mathrm{t}=$ Year which takes value $1,2, \mathrm{n}$

$\mathrm{U}_{\mathrm{t}}=$ Disturbance term in year ' $\mathrm{t}$ '

' $a$ ' and 'b' are parameters to be estimated.

The equation (1.1) was transformed into loglinear form and written as:

$\log Y=\log a+t \log b+\log U_{t}$

Equation (1.2) was estimated by using ordinary least square (OLS) technique.

Compound growth rate (g) was then estimated by the identity given in equation

$\wedge \wedge$

$\mathrm{g}=(\mathrm{b}-1)^{*} 100$

Where,

$\wedge$

$\mathrm{g}=$ Estimated compound growth rate in per cent per annum.

$\wedge$

$b=$ Antilog of $\log b$

The standard error of the growth rate was estimated and tested for its significance with't' statistic.

\section{Markov chain analysis}

The Markov chain analysis is an application of dynamic programming to the solution of a stochastic decision process that can be described by a finite number of states. The Markov process was used to study the shifts in the shares of land use categories thereby gain in understanding about the dynamics of the changes in land use. Shift in land use pattern was analyzed using the first order
Markov chain approach. Central to Markov chain analysis is the estimation of the transitional probability matrix $(\mathrm{P})$. The elements $\mathrm{Pij}$ of the matrix $\mathrm{P}$ indicates the probability that area under different uses will switch from one pattern $i$ to another $j$ with the passage of time. In the context of the current application, from $1995-96$ to 2014-15; 5 major forms of land utilization were considered to study the dynamics in land use pattern wherein only six components can be accommodated in the model. Hence, nine-fold classification of land use pattern was adopted under a fivefold classification of land use categories. These categories include, 1) FOR : Forest land, 2) LNAFC: Land not available for cultivation which comprises of Land put to nonagricultural uses (LNAU) and Barren and uncultivable land (BAUL), 3) OULEF: Other uncultivated land excluding fallow land which is a group of Permanent pastures and other grazing lands (PP), Land under miscellaneous tree crops and groves (LUMTC) and Cultivable waste (CW), 4) FL: Fallow lands included following land use categories Fallow lands other than current fallows (FOTCF) and Current fallows (CF), 5) NAS: Net area sown

$\mathrm{W}_{\mathrm{jt}}=\mathrm{SW}_{\mathrm{i}} \mathrm{t}-1 \mathrm{P}_{\mathrm{ij}}+\mathrm{U}_{\mathrm{jt}} \mathrm{i}=1 \ldots(4)$

or in matrix form it can be written as

$Y j=X j P j+U j$

Where,

$\mathrm{Yj}$ is a (Tx1) vector of observations reflecting the proportion in land use pattern in time $t$,

$\mathrm{Xj}$ is a (Txr) matrix of realized values of the proportion in land use pattern I in time $\mathrm{t}-1$,

$\mathrm{Pj}$ is a (rx1) vector of unknown transition parameters to be estimated and $\mathrm{Uj}$ is a vector of random disturbances. 


\section{Results and Discussion}

\section{Trends in different land-use classes}

To find the trends in different land-use classes in North- Eastern Karnataka, both compound growth rates and percentage changes in each class were estimated (Table 1). The percentage changes have revealed a decline ($2.52 \%$ ) in the total reported area which necessitates proper land-use surveys through remote sensing.

Growth rates were worked out for different land use categories to get a more detailed picture on spatial and temporal dimensions of the use pattern in the selected districts, NEK region, state and country as a whole. The results (Table 2 - Table 4) revealed the growth rates in forest cover, barren and uncultivable land, land put to non-agricultural uses, permanent pastures and other grazing land, cultivable wastes, land under miscellaneous tree crops and groves, current fallows, fallows other than current fallow, net area sown, area sown more than once and total cropped area.

The findings of the study attributed that negative growth was noticed in Ballari ($0.78 \%)$ and NEK $(-0.26 \%)$ region as a whole for the area under forest land and barren and uncultivable lands whereas, stagnant growth rates were found in Raichur and Koppal districts in both the categories of land use. However, positive growth rates were observed in case of forest area and negative growth rates in case of barren and uncultivable lands in the state and country as a whole during overall study period. Wani $e t$ al., (2009) reported the similar result of decrease in area under forest while studying the land use dynamics in Jammu and Kashmir. However, area under forest increased significantly in Karnataka state as whole and also at the national level.
Ramaswamy et al., (2005) reported the similar results of increase in area under forest while studying the dynamics of land use pattern in Tamil Nadu.

Despite the fact that area under forest has shown fluctuating trend, it was still far below the norms set under the National Forest Policy (1952) and it is unlikely to reach the target set by the New forest policy (1998). The Government and non-governmental organizations with public partnership should implement strong afforestation and efficient forest resource management programmes to bring desired result in enhancing the forest area in NEK region. On the other hand, area under barren and uncultivable land has shown a declining trend because most of the barren and uncultivable lands were diverted for nonagricultural uses after its development through reclamation measures. Goswami and Challa (2004) and Aravind (2010) also noticed the similar results in their studies conducted in Indian land use scenario and land use and cropping pattern in Northern transitional zone of Karnataka respectively.

Land under non-agricultural uses showed a sizeable increase in its area in all the selected districts and NEK region as a whole, Karnataka and India. This was mainly because of rapid growth in urbanization and industrialization consequent increase in population pressure in both the periods as well as in the overall period. Similar trend of increase in the area with respect to land put to non-agricultural uses was witnessed in the study conducted by Wani et al., (2009) in Jammu and Kashmir and at the all India level by Bardhan and Tewari (2010). On the other hand, area under barren and uncultivable land has shown a declining trend because most of the barren and uncultivable lands were diverted for non-agricultural uses after its development through reclamation measures. 
The area under permanent pastures and other grazing lands, cultivable waste and miscellaneous tree crops and other groves have experienced a declining trend in Ballari and Koppal, while cultivable waste lands and miscellaneous tree crops and other groves have exhibited positive and stagnant growth in Kalaburgi and Raichur districts. Moreover, North Eastern Karnataka region, state and country as a whole also resulted decreasing trend implying the diversion of the area from these categories to other purposes.

Area under current fallows and fallows other than current fallow noticed a mixed growth trends in study districts, NEK region, Karnataka and India as whole. The result of the current study also revealed that the area under current fallows showed a significant positive growth in the state and country as a whole while, negative growth was noticed in NEK region. The considerable increase in fallows other than current fallow for the overall study period might be due to increase in non-agricultural income, scarcity of labour in agriculture and a high demand for land under non-agricultural uses consequent to high land price. This consequence might be the reason for decline in the net sown area under dry zone areas which is more prone to frequent draughts as a result of variations in rainfall pattern year to year thereby showing inverse relationship between rainfall and current fallows. The results of the present study are corroborated with the study conducted by Sreeja (2004) and Goswami and Challa (2006).

Table.1 Share of different land use categories in North Eastern Karnataka

\begin{tabular}{|c|c|c|c|c|}
\hline $\begin{array}{l}\text { Sl. } \\
\text { No. }\end{array}$ & Land use category & 1995-96 & 2014-15 & $\%$ change \\
\hline 1 & Area under forests & $\begin{array}{r}260 \\
(5.78)\end{array}$ & $\begin{array}{r}241 \\
(5.50)\end{array}$ & -7.30 \\
\hline 2 & Barren and uncultivable lands & $\begin{array}{r}181 \\
(4.03)\end{array}$ & $\begin{array}{r}172 \\
(3.93)\end{array}$ & -4.97 \\
\hline 3 & Land put to non-agricultural uses & $\begin{array}{r}219 \\
(4.88)\end{array}$ & $\begin{array}{r}263 \\
(6.00)\end{array}$ & 20.09 \\
\hline 4 & Permanent pastures and other grazing lands & $\begin{array}{r}94 \\
(2.10)\end{array}$ & $\begin{array}{r}91 \\
(2.09)\end{array}$ & -3.19 \\
\hline 5 & Cultivable wastes & $\begin{array}{r}73 \\
(1.63) \\
\end{array}$ & $\begin{array}{r}69 \\
(1.57)\end{array}$ & -5.47 \\
\hline 6 & Miscellaneous tree crops and groves & $\begin{array}{r}31 \\
(0.69) \\
\end{array}$ & $\begin{array}{r}30 \\
(0.68) \\
\end{array}$ & -3.22 \\
\hline 7 & Current fallows & $\begin{array}{r}455 \\
(10.13)\end{array}$ & $\begin{array}{r}487 \\
(11.13)\end{array}$ & 7.03 \\
\hline 8 & Fallows other than current fallow & $\begin{array}{r}117 \\
(2.60)\end{array}$ & $\begin{array}{r}216 \\
(4.93) \\
\end{array}$ & 84.62 \\
\hline 9 & Net area sown & $\begin{array}{r}3062 \\
(68.16)\end{array}$ & $\begin{array}{r}2810 \\
(64.16)\end{array}$ & -8.22 \\
\hline 10 & Total reported area & $\begin{array}{r}4492 \\
(100.00)\end{array}$ & $\begin{array}{r}4379 \\
(100.00)\end{array}$ & -2.52 \\
\hline
\end{tabular}

Note: Figures in parentheses indicate percentage to the respective total reported area 
Table.2 District wise growth rates in land use categories in North Eastern Karnataka (1995-96 to 2014-15)

\begin{tabular}{|c|c|c|c|c|c|c|c|}
\hline Sl. No. & Land use category & Ballari & Bidar & Kalaburgi & Koppal & Raichur & NEK region \\
\hline 1 & Area under forests & $-0.78 * *$ & $0.62 * *$ & $0.02 * *$ & 0.00 & 0.00 & $-0.26 * *$ \\
\hline 2 & Barren and uncultivable lands & $-0.42 * *$ & $-0.74 * *$ & $-0.02 * *$ & 0.00 & 0.00 & $-0.23 * *$ \\
\hline 3 & Land put to non-agricultural uses & $2.12 * *$ & $0.11 * *$ & $0.54 * *$ & $0.07 *$ & $0.01 * *$ & $0.98 * *$ \\
\hline 4 & Permanent pastures and other grazing lands & $-0.98 * *$ & $-0.37 * *$ & $-0.04 *$ & $-0.005^{*}$ & $-0.32 * *$ & $-0.11 * *$ \\
\hline 5 & Cultivable wastes & $-0.46^{* *}$ & $0.08 * *$ & 0.00 & $-0.71 *$ & 0.00 & $-0.19 * *$ \\
\hline 6 & Miscellaneous tree crops and groves & $-0.69 * *$ & $-0.12 * *$ & $0.40 * *$ & $-0.15^{*}$ & 0.00 & $-0.20 * *$ \\
\hline 7 & Current fallows & $0.07 * *$ & $3.58 * *$ & $-1.82 * *$ & $-6.06^{*}$ & $1.96 * *$ & $-0.28 * *$ \\
\hline 8 & Fallows other than current fallow & $5.88 * *$ & $3.61 * *$ & $-0.45 * *$ & $-18.3^{*}$ & $0.33 * *$ & $1.86 * *$ \\
\hline 9 & Net area sown & $-1.36 * *$ & $-0.70 * *$ & $0.20 * *$ & $0.56^{*}$ & $-0.56 * *$ & $-0.26 * *$ \\
\hline 10 & Area sown more than once & $3.46^{* *}$ & $-1.02 * *$ & $-0.35 * *$ & $2.06^{*}$ & $2.72 * *$ & $1.14 * *$ \\
\hline 11 & Total cropped area & $-0.52 * *$ & $-0.74 * *$ & $0.13 * *$ & $0.85 *$ & $-0.04 * *$ & $-0.02 * *$ \\
\hline
\end{tabular}


Table.3 Growth in land use categories in NEK region

\begin{tabular}{|c|l|c|c|c|}
\hline $\begin{array}{c}\text { Sl. } \\
\text { No. }\end{array}$ & Land use category & Period-I & Period- II & Overall \\
\hline $\mathbf{1}$ & Area under forests & $-0.96^{* *}$ & 0.00 & $-0.26^{* *}$ \\
\hline $\mathbf{2}$ & Barren and uncultivable lands & $-0.63^{* *}$ & $-0.07 * *$ & $-0.23^{* *}$ \\
\hline $\mathbf{3}$ & Land put to non-agricultural uses & $-0.20^{* *}$ & $2.79 * *$ & $0.98^{* *}$ \\
\hline $\mathbf{4}$ & Permanent pastures and other grazing lands & $-0.43^{* *}$ & 0.00 & $-0.11^{* *}$ \\
\hline $\mathbf{5}$ & Cultivable wastes & $-0.67 * *$ & $0.09 * *$ & $-0.19^{* *}$ \\
\hline $\mathbf{6}$ & Miscellaneous tree crops and groves & $-0.75^{* *}$ & $0.06^{* *}$ & $-0.20^{* *}$ \\
\hline $\mathbf{7}$ & Current fallows & $0.79 * *$ & $-0.26^{* *}$ & $-0.28^{* *}$ \\
\hline $\mathbf{8}$ & Fallows other than current fallow & $0.12^{* *}$ & $4.90^{* *}$ & $1.86^{* *}$ \\
\hline $\mathbf{9}$ & Net area sown & $-0.58^{* *}$ & $-0.42^{* *}$ & $-0.26^{* *}$ \\
\hline $\mathbf{1 0}$ & Area sown more than once & $-0.33^{* *}$ & $-2.56^{* *}$ & $1.14^{* *}$ \\
\hline $\mathbf{1 1}$ & Total cropped area & $-0.54 * *$ & $-0.81 * *$ & $-0.02^{* *}$ \\
\hline
\end{tabular}

Note: Period-I= 1995-96 to 2004-05, Period-II= 2005-06 to 2014-15

and over all $=1995-96$ to $2014-15$

** Significant at 1 percent level

*Significant at 5 per cent level

Table.4 Comparative growth in land use categories in Karnataka and India

\begin{tabular}{|c|c|c|c|c|}
\hline $\begin{array}{l}\text { Sl. } \\
\text { No. }\end{array}$ & Land use category & $\begin{array}{c}\text { NEK } \\
\text { Region }\end{array}$ & Karnataka & India \\
\hline 1 & Area under forests & $-0.26 * *$ & $0.02 *$ & $0.25 * *$ \\
\hline 2 & Barren and uncultivable lands & $-0.23 * *$ & $-0.09 *$ & $-0.33 * *$ \\
\hline 3 & Land put to non-agricultural uses & $0.98 * *$ & $0.75^{*}$ & $1.00 * *$ \\
\hline 4 & Permanent pastures and other grazing lands & $-0.11 * *$ & $-0.64 *$ & $-0.37 * *$ \\
\hline 5 & Cultivable wastes & $-0.19 * *$ & $-0.39 * *$ & $-0.68 * *$ \\
\hline 6 & Miscellaneous tree crops and groves & $-0.20 * *$ & $-0.69 * *$ & $-0.85 * *$ \\
\hline 7 & Current fallows & $-0.28 * *$ & $0.71 * *$ & $0.16^{* *}$ \\
\hline 8 & Fallows other than current fallow & $1.86^{* *}$ & $1.01 * *$ & $0.31 * *$ \\
\hline 9 & Net area sown & $-0.26 * *$ & $-0.16 * *$ & $-0.01 * *$ \\
\hline 10 & Area sown more than once & $1.14 * *$ & $2.11 * *$ & $1.33 * *$ \\
\hline 11 & Total cropped area & $-0.02 * *$ & $0.19 * *$ & $-0.20 * *$ \\
\hline
\end{tabular}

Note: ** Significant at 1 percent level

Note: ** Significant at 1 percent level

* Significant at 5 per cent level 
Table.5 Transitional probability matrix for land use categories in NEK region

\begin{tabular}{|l|c|c|c|c|c|c|}
\hline $\begin{array}{l}\text { Land use } \\
\text { Category }\end{array}$ & FOR & LNAFC & OULEF & FL & NAS \\
\hline $\begin{array}{l}\text { Period I (1995-96 to 2004-05) } \\
\text { FOR }\end{array}$ & $\mathbf{0 . 7 9}$ & 0.00 & 0.02 & 0.00 & 0.19 \\
\hline LNAFC & 0.00 & $\mathbf{0 . 0 0}$ & 0.03 & 0.97 & 0.00 \\
\hline OULEF & 0.27 & 0.17 & $\mathbf{0 . 5 3}$ & 0.00 & 0.03 \\
\hline FL & 0.00 & 0.08 & 0.02 & $\mathbf{0 . 1 5}$ & 0.75 \\
\hline NAS & 0.00 & 0.11 & 0.02 & 0.06 & $\mathbf{0 . 8 1}$ \\
\hline Period- II (2005-06 to 2014- 15) & & & & \\
\hline FOR & $\mathbf{1 . 0 0}$ & 0.00 & 0.00 & 0.00 & 0.00 \\
\hline LNAFC & 0.00 & $\mathbf{1 . 0 0}$ & 0.00 & 0.00 & 0.00 \\
\hline OULEF & 0.00 & 0.00 & $\mathbf{1 . 0 0}$ & 0.00 & 0.00 \\
\hline FL & 0.00 & 0.00 & 0.00 & $\mathbf{0 . 0 6}$ & 0.94 \\
\hline NAS & 0.00 & 0.00 & 0.00 & 0.21 & $\mathbf{0 . 7 9}$ \\
\hline
\end{tabular}

The results of the land use category analysis depicted that the net area sown has decreased substantially in all the study districts except Koppal and Kalaburgi while NEK region, Karnataka and India as a whole also experienced declining trend during the overall period. This might be due to increase in fallow land. Gupta and Sharma (2010) reported the similar results of decrease in area under net sown area while studying the dynamics of land utilization in Himachal Pradesh.

The area sown more than once showed a mixed growth trend. Positive growth rate was noticed in Ballari, Koppal, Raichur, Karnataka and India as a whole implying an improvement in the management of production technology on cultivable lands over a period of time and possibly due to the expansion in irrigation, accompanied by adoption of improved and short duration varieties, intensification in the use of chemicals and fertilizers, agricultural services extension and development of the new machineries in farming. It is important to note that negative growth trend was found in Bidar, Kalaburgi districts and NEK region as a whole implying that in view of the increasing current fallows and other fallows led to decrease in area under net area sown and also area sown more than once ultimately resulted declined in total cropped area in NEK region for the overall study period. This implies that inefficient utilization of irrigation facilities in the study area.

It was evident from the Table 5 that during period-I, among different land use categories, net area sown as reflected in high probability of retention of 0.81 per cent. One of the most stable land use category was area under forest probability of retention $(0.79 \%)$. Further, other uncultivated land excluding fallow land retains 53 per cent of its share in the total reported area. It is important to note that retention capacity of fallow land $(0.15 \%)$ pattern was observed to be poor. Land not available for cultivation with probability of retention of zero indicated that it was the most unstable component of land use categories.

During period-II, all land use categories considered in the study have shown stability except fallow land. Forest land, land not available for cultivation and other uncultivated land excluding fallow land have retained their complete shares. Fallow land 
has found to be highly unstable and could retain only 6 per cent of its previous years' share. It has lost (94\%) of its major share to net sown area. However it has gained only 21 per cent from the net area sown. Net sown area could retain 79 per cent of its previous years' share and lost 21 per cent to fallow land. Further, it gained 94 per cent from the fallow land category

Land not available for cultivation was highly unstable in period-I and was turned into highly stable in period -II which includes land put non- agricultural uses and category that may lead to unstable because of increase in demand for non-agricultural uses due to increase in population density. The forest land, other uncultivated land excluding fallow land and net sown area were more stable in both the periods. However, net sown area found to be comparatively more stable in Period-I compared to Period-II while, fallow land became highly unstable in the period- II. This shift might be due to good rainfall during study period lost its share to net area sown from previous years share. Goswami and Challa (2004) reported similar results in their study.

In conclusion, the area under forest was declined and likely to decline in the future. Further, forest cover in the study area is about 5.50 per cent which is far below the minimum suggested level of at least one-third of the geographical area. Efforts should be made to bring barren and uncultivable land under forest, could be intensified by aforestation through encouraging farmers to adopt agroforestry farming system on barren and uncultivable lands. The Govt. and NGO's with public partnership should implement a strong aforestation through creating awareness about importance of forest for balancing ecology and environment. The net sown area and grazing land have been declined during study period. However, there is a scope to explore new cultivable area by diverting about 7.0 per cent area from cultivable wastes and fallow land, while land used for non-agriculture purpose has increased. Therefore, land use policies should ensure that the pressure on cultivable area for want of land for other non-agricultural uses to be regulated from the view point of long term food security reasons.

\section{References}

Anonymous, 2015. Fully revised estimated of principal crops in Karnataka. DES Report: 74-94.

Aravind, K., 2010. Economics of land use and cropping pattern in northern transitional zone of Karnataka. M. Sc. (Agri) Thesis, Univ. Agric. Sci., Dharwad, Karnataka (India).

Bardhan, D. and Tewari, S. K., 2010. An investigation into land use dynamics in India and land under-utilisation. Indian J. Agri. Econ., 65 (4): 658-676.

Goswami, S. N. and Challa, O., 2004. Indian land use scenario: An overview. Agric. Situ India., 60 (12): 783 - 797.

Goswami, S. N. and Challa. O., 2006. Socioeconomic factors affecting land use in India. Agric. Situ. India., 60 (10): 615 623.

Gupta, S. and Sharma, R. K., 2010. Land utilization pattern in Himachal Pradesh: A district-wise analysis. Agric. Situ. India., 12 (4):250-266.

Sreeja, M., 2004. Land use dynamics in Kerala- An economic analysis. M.Sc. (Agri) Thesis, Univ. Agric. Sci., Dharwad.

Wani, M. H., Baba. S. H. and Shahid Yousuf, 2009. Land use dynamics in Jammu and Kashmir. Agric. Econ. Res. Rev., 22 (1): 145-154.

Ramaswamy, C., Balasubramanian, R. and Sivakumar, S. D., 2005. Dynamics of land use pattern with special reference 
to fallow lands- An empirical investigation in Tamil Nadu. Indian J. Agri. Econ., 60 (4):629-644.

Ramesh Chand, and Raju, S. S., 2009.
Instability in Indian agriculture during different phases of technology and policy. Indian J. of Agric. Econ., 64(2): 187-207.

\section{How to cite this article:}

Anupama, G., B. S. Reddy, Suresh S. Patil, G. M. Hiremath and Wali, V. B. 2020. Assessment of Spatio-Temporal Changes in Land Use Pattern in North- Eastern Karnataka Region. Int.J.Curr.Microbiol.App.Sci. 9(02): 2262-2271. doi: https://doi.org/10.20546/ijcmas.2020.902.256 